\title{
HELMINTH PARASITES OF TWAITE SHAD, ALOSA FALLAX (ACTINOPTERYGII: CLUPEIFORMES: CLUPEIDAE), FROM THE SOUTHERN BALTIC SEA
}

\author{
Jerzy ROKICKI, Leszek ROLBIECKI *, and Agnieszka SKÓRA \\ Division of Invertebrate Zoology, University of Gdańsk, Gdynia, Poland
}

\begin{abstract}
Rokicki J., Rolbiecki L., Skóra A. 2009. Helminth parasites of twaite shad, Alosa fallax (Actinopterygii: Clupeiformes: Clupeidae), from the southern Baltic Sea. Acta Ichthyol. Piscat. 39 (1): 7-10.
\end{abstract}

\begin{abstract}
Background. The twaite shad, Alosa fallax (Lacepède, 1803), is a migratory marine species which lives in North Atlantic and sporadically appears in the Baltic Sea. Parasites of the twaite shad are poorly known, especially those infecting the fish occurring in the Baltic.

Materials and Methods. Within 2003-2005, 100 individuals of A. fallax, caught in the southern Baltic, were examined for the presence of parasites following commonly used procedures.

Results. The parasites found represented Digenea: Diplostomum spp. and Nematoda: Contracaecum osculatum (Rudolphi, 1802), Hysterothylacium aduncum aduncum (Rudolphi, 1802), and Desmidocercella numidica (Seurat, 1920). The overall prevalence was $74.0 \%$, while mean intensity averaged 10.5 . The most frequent parasites were Diplostomum spp. $(62.0 \%, 10.5)$ and C. osculatum $(39.0 \%, 2.2)$. This study constitutes the first record of Diplostomum spp., C. osculatum, and D. numidica in twaite shad.

Conclusion. The parasite fauna of the twaite shad from the southern Baltic Sea is poorly diversified, but the intensity and prevalence of infections are relatively high.
\end{abstract}

Keywords: twaite shad, Alosa fallax, parasites, Baltic Sea

\section{INTRODUCTION}

The twaite shad, Alosa fallax (Lacepède, 1803), is a migratory marine species that ascends rivers to spawn. The species occurs in the North-East Atlantic from Scandinavia to the coasts of Morocco; it is also found in the Mediterranean and Black Seas and sporadically appears in the North- and Baltic Seas. In addition, there are lacustrine populations of this fish in Italy and southern Ireland. The systematics of the twaite shad is uncertain. Mentioned in the literature sub-species of $A$. fallax shall be often considered as ambiguous synonyms (Quignard and Douchement 1991, Froese and Pauly 2008). Very little is known about the occurrence of parasites in the twaite shad or on their impact on the species. Parasites of A. fallax from the southern Baltic had been studied only occasionally (Nybelin 1922, Hartwich 1975, PileckaRapacz 2003). The present paper reports on the occurrence of parasites in twaite shad in southern Baltic.

\section{MATERIALS AND METHODS}

The study, carried out from February 2003 to November 2005, involved a total of 100 twaite shad caught in the southern Baltic, mainly in the Gulf of Gdańsk. The fish weighed $130-1175 \mathrm{~g}( \pm 1 \mathrm{~g})$ and their total length (TL) ranged from 26.0 to $51.5 \mathrm{~cm}( \pm 0.1 \mathrm{~cm})$.
The fish age was determined from scales and otoliths. The age of 98 individuals was determined exact to 1 year. Otoliths of the remaining 2 individuals were illegible. The fish examined were 2-7-year-old. To investigate the relation between the severity of infection and fish age, the fish were subdivided into 4 age classes: the fish aged 2 (20 individuals), 3 (20), 4 (30), and older than 4 years (26).

The condition of the fish was determined with the Fulton $(F)$ formula:

$$
F=100 \mathrm{~W} \cdot L^{-3}
$$

where: $W=$ fish weight $[\mathrm{g}]$, and $L=$ total fish length [cm]. After delivery to the laboratory, the fish were subjected to standard procedures of parasitological examination and the metazoan parasites were identified. Metacercariae were removed from the fish eye-lens, killed in hot water, fixed in $70 \%$ alcohol, stained with Gowers alum carmine, dehydrated in ethyl alcohol series, and cleared with benzyl alcohol. Nematodes were fixed in a mixture of glacial acetic acid and formalin, cleared in lactophenol, and embedded in glycerol-gelatine.

The following indicators were used to determine the infection level: prevalence (percentage of fish infected), mean intensity (mean number of parasite individuals per infected host), abundance (mean number of parasites per infected and non-infected fish), and intensity range

\footnotetext{
${ }^{*}$ Correspondence: Dr Leszek Rolbiecki, Katedra Zoologii Bezkręgowców, Uniwersytet Gdański, Al. Piłsudskiego 46, 81-378 Gdynia, Poland, phone: +48 58 523 6638, fax: +48585236630, e-mail: l.rolbiecki@ug.edu.pl
} 
(minimum and maximum number of parasite individuals per host in the infrapopulation under study).

\section{RESULTS}

The materials studied included a total of 774 individuals of parasites representing the digenean Diplostomum spp. and the nematodes Contracaecum osculatum (Rudolphi, 1802), L3; Desmidocercella numidica (Seurat, 1920), L3, and Hysterothylacium aduncum aduncum (Rudolphi, 1802). The overall prevalence was $74.0 \%$ at a mean intensity of 10.5 , abundance of 7.7 , and intensity range of $1-65$.

Diplostomum spp., represented by metacercariae, was the most abundant parasite. The fish eye-lenses yielded 649 digenean individuals. The digenean infection parameters were: prevalence $62.0 \%$, mean intensity 10.5 , abundance 6.5 , and intensity range $1-53$. The fish older than 4 years showed the highest prevalence of infection, while the mean intensity and the abundance of parasites were at their highest in the fish aged 4 years (Fig. 1).

Another species of helminth present was the stage 3 larvae of Contracaecum osculatum, 85 of them being found in the liver and on the pyloric caeca. The C. osculatum infection parameters were: prevalence $39.0 \%$, mean intensity 2.2 , abundance 0.9 , and intensity range $1-8$. The magnitude of infection was observed to increase with fish age (Fig. 2).

The stage 3 larvae of Desmidocercella numidica (26 individuals) were found in the vitreous body of two individuals aged 4 years. Infection parameters for D. numidica were: prevalence $2.0 \%$, mean intensity 13.0 , abundance 0.3 , and intensity range 10-16.

Hysterothylacium aduncum aduncum was the least frequent parasite identified during the examination of the fish; 14 individuals were found in the pyloric caeca ( 6 nematode females and 3 males) and in the intestine ( 4 females and an individual of indeterminate sex). A single nematode was found in the twaite shad aged 2 years; the fish aged 3, 4, and older than 4 years yielded 2, 6, and 5 nematode individuals, respectively. The $H$. aduncum aduncum infection parameters were: prevalence $11.0 \%$, mean intensity 1.3 , abundance 0.1 , and intensity range $1-3$.

The mean condition coefficient of non-infected twaite shad was higher (0.96) than that (0.91) for the infected fish, regardless of the parasite species.

\section{DISCUSSION}

The twaite shad caught in the southern Baltic was found to support 4 parasitic taxa: Diplostomum spp., Contracaecum osculatum, Desmidocercella numidica, and Hysterothylacium aduncum aduncum. This study constitutes the first record of Diplostomum spp., Contracaecum osculatum and D. numidica in the twaite shad.

Earlier studies on the twaite shad parasite fauna in the Baltic Sea showed the presence of the cestode Eubothrium fragile (Rudolphi, 1802), the nematodes Raphidascaris acus (Bloch, 1799) and Anisakis simplex (Rudolphi, 1809), and the acanthocephalan
Pomphorhynchus laevis (Müller, 1776) (cf. Nybelin 1922, Hartwich 1975, Pilecka-Rapacz 2003).

The majority of the parasitic species listed above can complete their life cycles in the Baltic Sea. The exception is primarily Eubothrium fragile whose presence may be indicative of the twaite shad migration from the areas of occurrence of the cestode and its intermediate host, i.e., from the North Sea. Kennedy (1978, 1981) regarded E. fragile as a marine species inhabiting waters with elevated salinity; the cestode is also a parasite typical of the twaite shad. In the past, Nybelin (1922) did find the presence of $E$. fragile in the Baltic and recognised this as evidence of the host immigration from the Danish straits. Aprahamian (1985) was of the opinion that E. fragile may be used as an indicator of fish migrations.

Another typically marine parasite, A. simplex is noteworthy. Anisakis simplex is recorded in the Baltic primarily in spring and autumn, in the spring and autumn herring populations (see, e.g., Rolbiecki and Rokicki 2002, Szostakowska et al. 2005) entering the Baltic to spawn. Apart from herring, the nematodes have been reported from three-spined stickleback, Gasterosteus aculeatus aculeatus L. (cf. Podolska and Morozińska 1994), zander, Sander lucioperca (L.) (cf. Rolbiecki and Rokicki 2000), and flounder, Platichthys flesus (L.) (cf. Køie 1999) throughout the year. As the intermediate hosts of A. simplex, the Euphausiacea, are absent in the Baltic, larger fish, such as twaite shad and zander, are infected having preyed upon the infected herring.

Presently recovered nematodes-C. osculatum and H. aduncum aduncum - are typical marine species, however Diplostomum spp., and D. numidica are freshwater parasites. At least Diplostomum spp., but possibly also D. numidica are demonstrating the tolerance for changes to salinities and they are often brought by hosts to waters with higher salinity. Apart from that, these parasites are noted in the Baltic Sea. It is worth noting that twaite shad spawn in rivers and estuaries (Heese 2000), and may accumulate freshwater parasites and simultaneously lose marine ones during this phase in their life history. This may explain the fall in infections by some parasites of twaite shade during their spawning migrations reported by Aprahamian (1985).

The twaite shad in the southern Baltic showed an increased infection with Diplostomum spp. and C. osculatum as the fish grew older (Figs. 1, 2). Variability in fish length-dependent infection is affected by numerous factors (Williams and Jones 1994, Bush et al. 2001). Some parasites actively invade potential hosts, while others are passively transmitted into a fish with water when the fish breathes. Many of parasites reach a fish during theirs feeding on various invertebrates and vertebrates. Infective cercariae of the digenean Diplostomum spp. actively invade potential hosts. Host size is an important factor affecting age-dependent increments of the infection level. Larger twaite shad may be more easily colonized by the cercariae. In addition, the larvae may live in the fish for as long as 5-6 years (Šigin 1986), which enhances their 


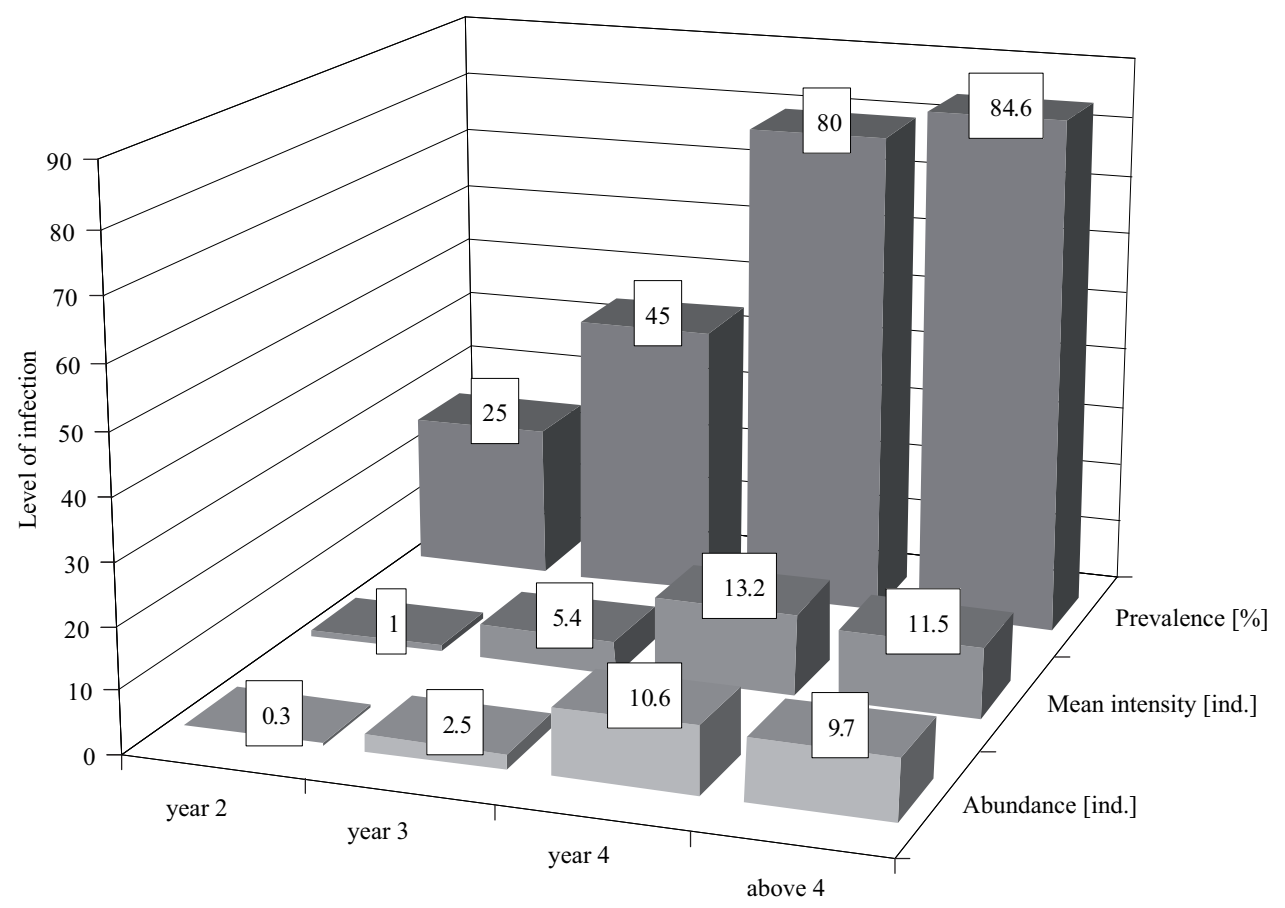

Fig. 1. Occurrence of Diplostomum spp. in the twaite shad belonging to different ages group

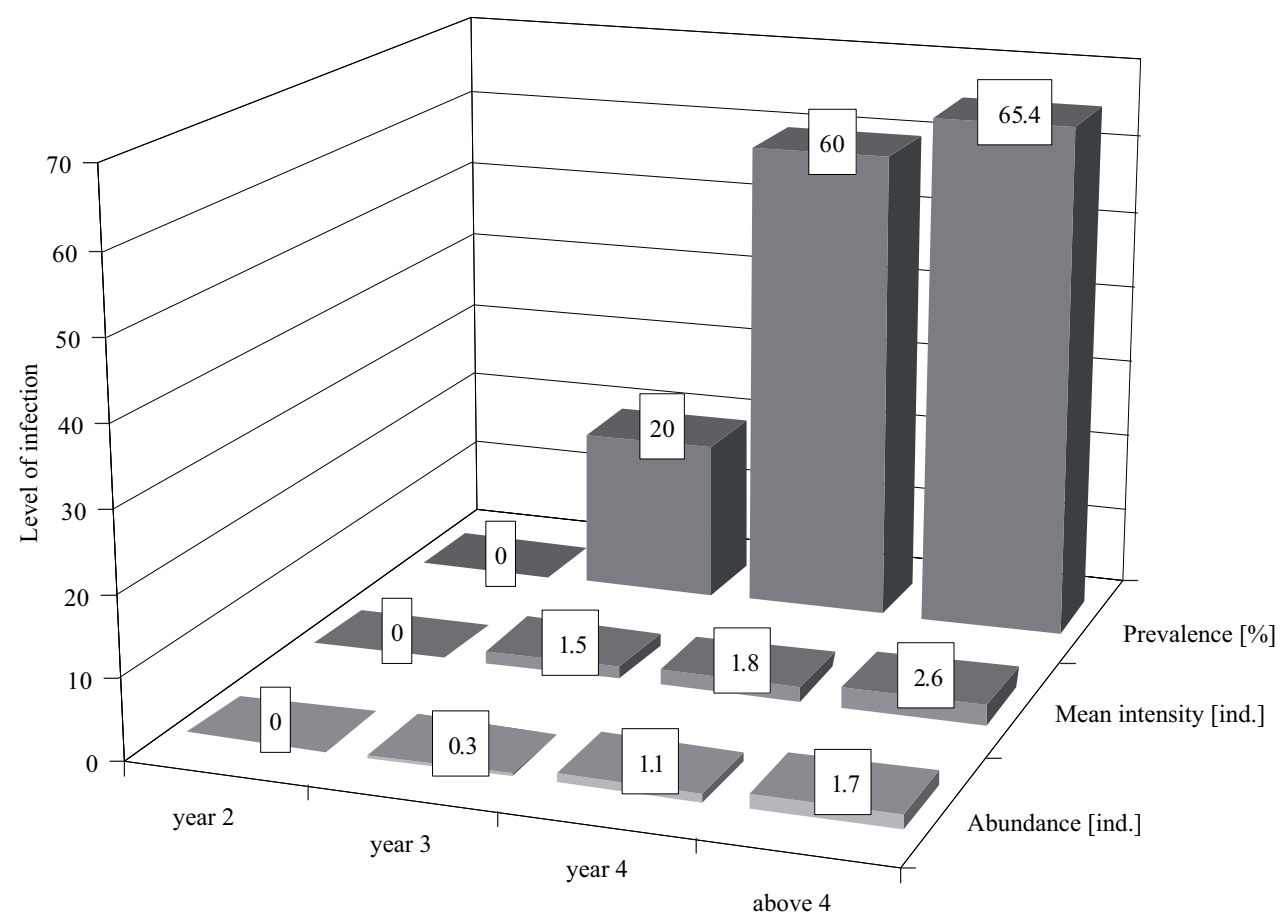

Fig. 2. Occurrence of Contracaecum osculatum in the twaite shad belonging to different ages group

accumulation in older fish, as mentioned by Valtonen et al. (1988) and Rolbiecki (2006). It is worth adding that the twaite shad life span is up to 10 years (Heese 2000), which may act in favour of accumulation of parasites, particularly their larvae. On the other hand, C. osculatum is ingested with copepod prey (the first intermediate hosts) or fish (second intermediate or paratenic hosts) (Moravec
1994), primary items of the twaite shad's diet. The young individuals ingest smaller food items, such as copepods, while the older fish supplement their diet with other zooplankters, insects, and plants; the juvenile twaite shad feeds on the fry of herring, sprat, and gobies as well as crustaceans, including the Mysidaceea and decapods. On the other hand, the adult twaite shad staying in the sea 
feed virtually exclusively on fish (Heese 2000) what can indicate for the great role of other fish as paratenic hosts in infecting of $A$. fallax, at simultaneously, mentioned earlier, accumulation of parasites.

As shown by the data collected in this study, these parasites may be detrimental to their host. The overall condition coefficient of the infected individuals (regardless of the helminth species) was lower than that in the parasitefree fishes. This could be affected by other pathogens, such as viruses, bacteria, or fungi, which were not investigated in this study. Condition index can be also affected by the fish life cycle, for example reproduction. Particularly visible is a decrease in condition of fish from spawning. One should not also exclude the possibility that fish in poorer condition may be more easily infected by parasites.

In summary, it can be concluded that the southern Baltic twaite shad helminth fauna is species-poor, but the infection levels are relatively high.

\section{ACKNOWLEDGEMENTS}

This study was supported by the Ministry of Science and Higher Education, Grant No. 0420/PO4/2005/28.

\section{REFERENCES}

Aprahamian M.W. 1985. The effect of the migration of Alosa fallax fallax (Lacépède), into fresh water, on branchial and gut parasites. Journal of Fish Biology 27: 521-532. DOI: 10.1111/j.1095-8649.1985.tb03199.x.

Bush A.O., Fernández J.C., Esch G.W., Seed J.R. 2001. Parasitism. The diversity and ecology of animal parasites. Cambridge University Press, Cambridge.

Froese R., Pauly D. (eds.) 2008. FishBase. World Wide Web electronic publication. www.fishbase.org. version (11/2008).

Hartwich G. 1975. Schlauchwürmer, Nemathelminthes Rundoder Fadenwürmer, Nematoda. Parasitische Rundwürmer von Wirbeltieren. 1. Rhabditida und Ascaridida. Vol. 62. In: Senglaub K., Hannemann H.J., Schumann H. (eds.) Die Tierwelt Deutschlands und der angrenzenden Meeresteile nach ihrer Merkmalen und nach ihrer Lebensweise. VEB Gustav Fischer Verlag, Jena.

Heese T. 2000. Alosa fallax (Lacepède, 1803). Pp. 173-178. In: Brylińska M. (ed.) Ryby słodkowodne Polski. [The freshwater fishes of Poland.] PWN, Warszawa. [In Polish.]

Kennedy C.R. 1978. The biology, specificity and habitat of the species of Eubothrium (Cestoda: Pseudophyllidea), with reference to their use as biological tags: a review. Journal of Fish Biology 12: 393-410. DOI: 10.1111/j.1095-8649.1978.tb04183.x.

Kennedy C.R. 1981. The occurrence of Eubothrium fragile (Cestoda: Pseudophyllidae) in twaite shad, Alosa fallax (Lacépède) in the River Severn. Journal of Fish Biology 19: 171-177. DOI: 10.1111/j.1095-8649.1981.tb05821.x.

Køie M. 1999. Metazoan parasites of flounder Platichthys flesus (L.) along a transect from the southwestern to the northeastern
Baltic Sea. ICES Journal of Marine Science 56: 157-163. DOI: $10.1006 /$ jmsc. 1999.0463 .

Moravec F. 1994. Parasitic nematodes of freshwater fishes of Europe. Academia, Praha.

Nybelin O. 1922. Anatomisch-systematische Studien über Pseudophyllideen. Göteborgs Kungelige Vetenskaps- och. vitterhets-samhälles handligar 4. följden 26: 1-288.

Pilecka-Rapacz M. 2003. Pasożyty młodzieży parposza Alosa fallax (Lacepede, 1803) z Zalewu Wiślanego [Parasites in the juvenile twaite shad Alosa fallax (Lacepède, 1803) with Vistula Lagoon]. Zeszyty Naukowe Uniwersytetu Szczecińskiego Acta Biologica 10: 147-152. [In Polish.]

Podolska M., Morozińska J. 1994. Anisakis simplex (larwa III stadium) u ciernika Gasterosteus aculeatus z południowego Bałtyku [Anisakis simplex (larva III-stage) in stickleback Gasterosteus aculeatus from Southern Baltic]. Wiadomości Parazytologiczne 40: 305-309. [In Polish.]

Quignard J.P., Douchement C. 1991. Alosa fallax fallax (Lacepède, 1803). Pp. In: Hoestland H. (ed.). The freshwater fishes of Europe. Vol. 2. Clupeidae, Anguillidae. AulaVerlag, Wiesbaden.

Rolbiecki L. 2006. Correlation between the occurrence of parasites and body length of roach, carp bream, European perch, zander, and ruffe in the Vistula Lagoon estuary. Oceanological and Hydrobiological Studies 35: 257-267.

Rolbiecki L., Rokicki J. 2000. The occurence of the nematodes Anisakis simplex pathogenic to man in pike-perch from the Vistula Lagoon, Poland. Wiadomości Parazytologiczne 46: 397-402.

Rolbiecki L., Rokicki J. 2002. III-stage Anisakis simplex (Rudolphi, 1809) (Nematoda; Anisakidae) larvae in herring caught in autumn from the Polish part of the Vistula Lagoon. Acta Scientarum Polonorum, Piscaria 1: 105-110.

Szostakowska B., Myjak P., Wyszyński M., Pietkiewicz H., Rokicki J. 2005. Prevalence of anisakin nematodes in fish from southern Baltic Sea. Polish Journal of Microbiology 54 (Suppl.): 41-45.

Šigin A.A. [Shigin A.A.] 1986. Trematody fauny SSSR. Rod Diplostomum, metacerkarii. [Trematodes of the fauna of the USSR. Genus Diplostomum, metacercariae.] Nauka, Moskva. [In Russian.]

Valtonen E.T., Fagerholm H.-P., Helle E. 1988. Contracaecum osculatum (Nematoda: Anisakidea) in fish and seals in Bothnian Bay (northeastern Baltic Sea). International Journal for Parasitology 18: 365-370. DOI: 10.1016/0020-7519(88)90146-4.

Williams H., Jones A. 1994. Parasitic worms of fish. Taylor and Francis, London, Bristol.

Received: 27 June 2008

Accepted: 22 February 2009

Published electronically: 20 May 2009 